Article

\title{
Imidazole Processing of Wheat Straw and Eucalyptus Residues-Comparison of Pre-Treatment Conditions and Their Influence on Enzymatic Hydrolysis
}

\author{
Pedro M. A. Pereira, Joana R. Bernardo, Luisa Bivar Roseiro (D), Francisco Gírio (D) and Rafał M. Łukasik*(D)
}

check for updates

Citation: Pereira, P.M.A.; Bernardo, J.R.; Roseiro, L.B.; Gírio, F.; Łukasik, R.M. Imidazole Processing of Wheat Straw and Eucalyptus

Residues-Comparison of

Pre-Treatment Conditions and Their Influence on Enzymatic Hydrolysis. Molecules 2021, 26, 7591. https:// doi.org/10.3390/molecules26247591

Academic Editor: Juan Antonio Cecilia

Received: 21 November 2021 Accepted: 13 December 2021 Published: 15 December 2021

Publisher's Note: MDPI stays neutral with regard to jurisdictional claims in published maps and institutional affiliations.

Copyright: (c) 2021 by the authors. Licensee MDPI, Basel, Switzerland. This article is an open access article distributed under the terms and conditions of the Creative Commons Attribution (CC BY) license (https:// creativecommons.org/licenses/by/ $4.0 /)$.
Laboratório Nacional de Energia e Geologia, I. P., Unidade de Bioenergia e Biorrefinerias, Estrada do Paço do Lumiar 22, 1649-038 Lisbon, Portugal; pedro18broca@gmail.com (P.M.A.P.); joana-bernardo@bioref-colab.pt (J.R.B.); luisa.roseiro@lneg.pt (L.B.R.); francisco.girio@lneg.pt (F.G.)

* Correspondence: rafal.lukasik@lneg.pt

Abstract: Biomass pre-treatment is a key step in achieving the economic competitiveness of biomass conversion. In the present work, an imidazole pre-treatment process was performed and evaluated using wheat straw and eucalyptus residues as model feedstocks for agriculture and forest-origin biomasses, respectively. Results showed that imidazole is an efficient pre-treatment agent; however, better results were obtained for wheat straw due to the recalcitrant behavior of eucalyptus residues. The temperature had a stronger effect than time on wheat straw pre-treatment but at $160{ }^{\circ} \mathrm{C}$ and $4 \mathrm{~h}$, similar results were obtained for cellulose and hemicellulose content from both biomasses (ca. $54 \%$ and $24 \%$, respectively). Lignin content in the pre-treated solid was higher for eucalyptus residues (16\% vs. $4 \%$ ), as expected. Enzymatic hydrolysis, applied to both biomasses after different pre-treatments, revealed that results improved with increasing temperature/time for wheat straw. However, these conditions had no influence on the results for eucalyptus residues, with very low glucan to glucose enzymatic hydrolysis yield ( $93 \%$ for wheat straw vs. $40 \%$ for eucalyptus residues). Imidazole can therefore be considered as a suitable solvent for herbaceous biomass pre-treatment.

Keywords: pre-treatment; imidazole; hardwood; biomass; biorefinery

\section{Introduction}

There is a growing demand for solutions providing integration and flexibility in the European energy system. These solutions should create flexibility between intermittent electricity and sustainable fuel production and, at the same time, enable production under economically competitive conditions from alternative carbon sources [1-4]. To accomplish this objective, it is essential to develop flexible, selective, robust and less energy-demanding integrated pre-treatments with the simultaneous separation of contaminants, as well as optimization of pre-treatment technologies compatible with the use of multiple feedstocks. This includes the efficient utilization of resources to produce purified fractions of carbohydrates, lignin and other compounds for further processing and conversion into a wide spectrum of products, such as proteins, biopolymers, organic acids, and furfural and its derivatives [5-7].

The selection of the pre-treatment method depends on the biomass type as well as the desired product, e.g., the delivery of upgradable sugars or lignin-derived commodities. Several pre-treatment technologies are currently employed to overcome the recalcitrance of lignocellulose, to increase hydrolysis efficiency and to improve the yields to monomeric sugars [8-11]. Among them are mostly chemical methods, e.g., with acids or alkali. Nevertheless, novel biomass pre-treatment protocols, such as those based on non-hazardous catalysts and/or green solvents that simultaneously enable a reduction in the number of hydrolytic enzymes needed for cellulose hydrolysis and for the fermentation inhibitors, are still required. At the same time, these are the core options to obtain lignin (or its derivatives) 
and pure sugar streams [12-15]. Subsequently, these streams can work as feedstock for fermentation into biofuels and other value-added applications.

Imidazole, along with ionic liquids [16-19], high-pressure fluids [20-22], and deep eutectic solvents $[23,24]$, belongs to these new pre-treatment options and, up until now, has demonstrated considerable potential in the valorization of biomass, especially in the context of biorefinery [4] focused on value-added products. Imidazole, being an environmentally benign and non-hazardous solvent, turns the process of biomass pre-treatment into an attractive alternative, offering the possibility of delivering a depolymerized lignin and highly hydrolyzable polysaccharide fraction $[25,26]$. As such, the imidazole processing of biomass is similar to that presented by organosolv pre-treatment $[27,28]$.

The present work describes the application of imidazole pre-treatment in two representative feedstocks of lignocellulosic residues, one of agricultural origin (wheat straw) and the other of forest origin (eucalyptus residues). Wheat straw and eucalyptus residues are two major lignocellulosic feedstocks for sustainable bioeconomic development in Europe. Subsequently, pre-treated solids of both biomasses rich in polysaccharides are scrutinized for the ability to originate concentrated reducing sugar streams, obtained in the enzymatic saccharification process.

\section{Experimental Section}

\subsection{Materials}

The wheat straw sample was delivered by ECN (Energy Research Center of the Netherlands), from The Netherlands. The eucalyptus residues were kindly provided by The Navigator Company from their papermill in Cacia, Portugal. Wheat straw and eucalyptus residues moisture contents were found to be 9.8 and $8.4 \mathrm{wt} \%$, respectively, and were determined using an AMB-50 moisture analyzer (Adam Equipment Inc., Oxford CT, USA).

Both feedstocks were ground with a knife mill, IKA ${ }^{\circledR}$ WERKE, MF 10 basic (Staufen, Germany), into particles smaller than $0.5 \mathrm{~mm}$, homogenized in a defined lot, and stored in plastic containers at room temperature prior to further use.

For the pre-treatment experiments and post-reaction processing, the following reagents were used: imidazole with a purity of $99 \% \mathrm{w} / \mathrm{w}$, purchased from Alfa Aesar, (Karlsruhe, Germany), $\mathrm{NaOH}$ pellets (99\% purity) supplied by Eka Chemicals/Akzonobel (Bohus/Sweden); $25 \% \mathrm{HCl}$ aqueous solution prepared from $37 \% \mathrm{HCl}$ solution (VWR Chemicals/AnalaR NORMAPUR ${ }^{\circledR}$, Alfragide, Portugal)) using ultrapure water $(18.2 \mathrm{M} \Omega / \mathrm{cm})$ produced via the PURELAB Classic of Elga system; $\mathrm{HCl}$ solution with a $\mathrm{pH}$ of 2, prepared from distilled water and a $25 \% \mathrm{HCl}$ solution; $96 \%$ ethanol (v/v) and acetonitrile at $99.9 \%$ purity, both from the Carlo Erba Group, Aresa, Italy. For filtration, cloth (made from a cotton shirt), paper $\left(\varnothing=150 \mathrm{~mm}, \mathrm{n} .1238\right.$, acquired from Filter-Lab ${ }^{\circledR}$, Filtros Anoia, S.A. Barcelona, Spain) and nylon filters $\left(0.45 \mu \mathrm{m}\right.$, also from Filter-Lab ${ }^{\circledR}$, Filtros Anoia, S.A. Barcelona, Spain) were used.

Glucose ( $\geq 98$ wt \%, Merck, Darmstadt, Germany), xylose ( $\geq 98$ wt \%, Merck, Germany), arabinose ( $\geq 98 \mathrm{wt} \%$, Merck, Germany), furfural (99 wt \%, Sigma-Aldrich, Germany), 5-hydroxymethylfurfural (99 wt \%, Sigma-Aldrich, Taufkirschen, Germany) and acetic acid (glacial, $99.8 \mathrm{wt} \%$, Merck, Darmstadt, Germany) were used for the qualitative and quantitative HPLC analyses of the obtained liquids and solids. Sulfuric acid (96 wt \%, Panreac, Barcelona, Spain) was used to prepare the mobile phase for the HPLC analyses (5 mM sulfuric acid).

For the enzymatic hydrolysis assays, $0.1 \mathrm{M}$ sodium citrate buffer ( $\mathrm{pH} 4.8$ ) prepared from citric acid monohydrate ( $99.7 \%$ purity) and tris-sodium citrate ( $>99 \%$ purity), both from VWR International Ltd. (Leicester, England), and $2 \mathrm{wt} \%$ sodium azide solution were used. Celli ${ }^{\circledR} \mathrm{C}$ Tec2 (Cellulase, enzyme blend) solution, kindly provided by Novozymes Europe, Denmark, was employed in the enzymatic reaction. 


\subsection{Biomass and Pre-Treated Solid Characterization}

Both biomasses and pre-treated solids were characterized according to the NREL method [29], to determine the total moisture, total lignin and polysaccharide contents. Acid-insoluble lignin was determined gravimetrically, while the acid-soluble lignin content was established using UV spectrophotometry. The content of glucan and hemicelluloses (xylan, arabinan, and acetyl groups) was determined using high-performance liquid chromatography (HPLC). Furthermore, for native biomasses, total extractives, ash and protein contents were determined according to the standard methods-NREL/TP-510-42619 [30], NREL/TP-510-42622 [31] and ISO 8968-1:2014 [32], respectively. All analyses were conducted in duplicate and are presented as mean values.

\subsection{Biomass Processing}

The pre-treatment of biomass with imidazole was carried out on the basis of a previously developed method presented elsewhere [15] and is outlined in Figure 1. For all the experiments, $5 \mathrm{~g}$ of air-dried biomass and $45 \mathrm{~g}$ of imidazole were placed into a $100 \mathrm{~mL}$ Schott flask. The reaction vessel was then placed in an oil bath to guarantee continuous and controlled stirring and heating. Reaction time started from the moment when the desired temperature was reached. The reaction temperature and time were in the range of $130-160^{\circ} \mathrm{C}$ and 2 to $4 \mathrm{~h}$. When the process ended, the flask containing the mixture was removed from the bath and cooled down to $90{ }^{\circ} \mathrm{C}$; then, $90 \mathrm{~mL}$ distilled water was added slowly. Next, the obtained mixture was transferred to a $500 \mathrm{~mL}$ Erlenmeyer flask and stirred for $1 \mathrm{~h}$. This step promoted the precipitation of pulp, which was collected and oven-dried at $45^{\circ} \mathrm{C}$ for $24 \mathrm{~h}$.

\section{Biomass}

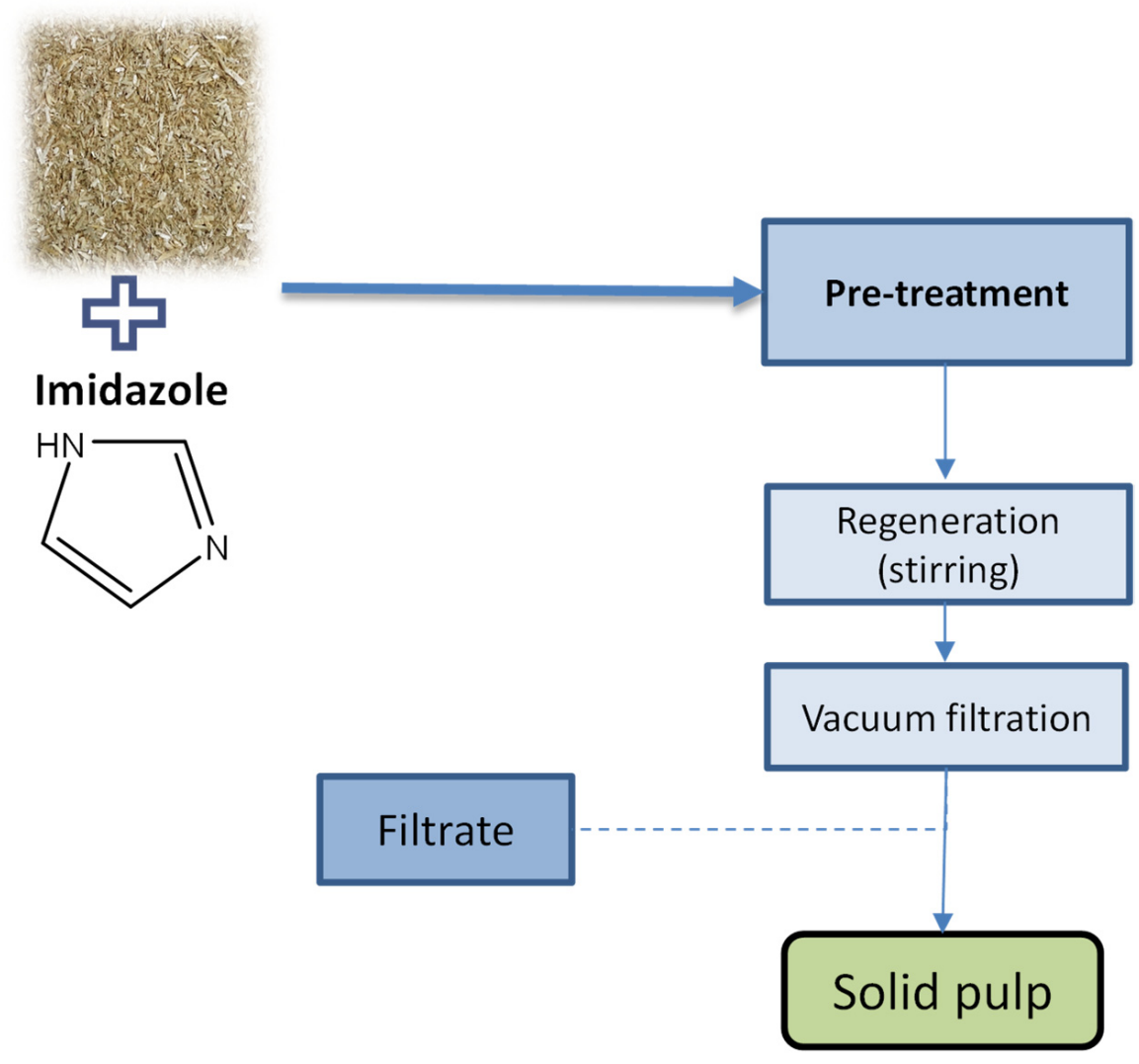

Figure 1. The procedure of biomass pre-treatment with imidazole. 


\subsection{Enzymatic Hydrolysis of Solids}

Enzymatic hydrolysis assays were performed to evaluate the effect of pre-treatment on glucan and xylan conversion to their corresponding monomers. The adopted procedure was based on the standard NREL protocol [33]. For this purpose, native biomasses and pre-treated materials were subjected to enzymatic hydrolysis at a $2 \% \mathrm{w} / \mathrm{v}$ total solids (dry weight basis) concentration in $50 \mathrm{~mL}$ vials, with $5 \mathrm{~mL}$ of $0.05 \mathrm{M}$ sodium citrate buffer ( $\mathrm{pH}$ of 5), prepared from citric acid monohydrate and tris-sodium citrate, and $100 \mu \mathrm{L}$ of a $2 \mathrm{wt} \%$ sodium azide solution to prevent the undesired growth of microorganisms. Distilled water was added to reach the $5.0 \mathrm{~mL}$ total volume, taking into account the volume of enzyme added. The enzyme loading was $60 \mathrm{FPU} / \mathrm{g}$ glucan of Celli ${ }^{\circledR} \mathrm{CTec} 2(199.9 \mathrm{FPU} / \mathrm{mL})$. The enzymatic hydrolyses were performed in a shaking incubator (Optic Ivymen systemMadrid, Spain) at $180 \mathrm{rpm}$ and $50{ }^{\circ} \mathrm{C}$. Reaction blanks for both the substrate and the enzyme solution were carried out under the same experimental conditions.

At the desired reaction time points $(1,4,6,24,48$ and $72 \mathrm{~h})$, a $0.1 \mathrm{~mL}$ sample was taken, diluted, filtered through a $0.45 \mathrm{~mm}$ filter and analyzed via HPLC. All enzymatic hydrolysis assays were performed in duplicate.

The glucose and xylose yields were calculated according to the following formulas: Glucose yield $(\%)=\frac{\frac{162}{180} \times[\text { glucose }] \times V}{\mathrm{x}_{\text {celluluse }} \text {-rich solid } \times \text { glucan content }} \times 100$ and Xylose $\operatorname{yield}(\%)=\frac{\frac{132}{150} \times[\mathrm{xylose}] \times \mathrm{V}}{x_{\text {cellulose-rich solid }} \times \text { xylan content }} \times 100$, where the [glucose] and [xylose] concentrations were measured in $\mathrm{g} / \mathrm{L}$ obtained in the hydrolysate, the values $\frac{162}{180}$ and $\frac{132}{150}$ are the dehydration factors, $\mathrm{V}$ is the volume of solution in $\mathrm{L}, \mathrm{x}_{\text {cellulose-rich solid }}$ refers to the cellulose-rich fraction in dry weight biomass, used in the enzymatic hydrolysis and expressed in g, and glucan or xylan contents refer to their contents in the solid fraction used for the enzymatic hydrolysis.

\subsection{Chemical Analysis}

HPLC Analysis

The liquid phases obtained from the pre-treatment of biomass with imidazole and enzymatic hydrolyses were analyzed using an Agilent 1100 series machine with a Bio-Rad Aminex HPX-87H column (Bio-Rad, Hercules, CA, USA). The liquids obtained from the characterization of native and pre-treated biomass were also analyzed by HPLC. Analyses were performed at $65^{\circ} \mathrm{C}$, with $5 \mathrm{mmol} / \mathrm{L} \mathrm{H}_{2} \mathrm{SO}_{4}$ used as the mobile phase, at a flow rate of $0.6 \mathrm{~mL} / \mathrm{min}$. The detection was performed using an RID (refractive index detector) for monosaccharides (glucose, xylose and arabinose) and acetic acid, and a DAD (diode array detector) at $280 \mathrm{~nm}$ wavelength for furans (furfural (furan-2-carbaldehyde) and 5 -HMF $\equiv 5$-hydroxymethylfurfural (5-(hydroxymethyl)-2-furaldehyde)). The quantitative analyses were performed using the external calibration method with standard solutions.

\section{Results and Discussion}

\subsection{Biomass Composition}

The composition of both biomasses in their native form was determined, and the obtained results are summarized in Table 1.

The obtained results demonstrate that the eucalyptus residues contain almost $20 \%$ more cellulose than wheat straw. However, in the case of cellulose and hemicellulose, the content of these polysaccharide fractions was very similar for both biomasses, above $60 \%$ that of native feedstocks. On the other hand, the difference in lignin content in both biomasses was more noticeable. Eucalyptus residues contained twice the lignin of wheat straw. Regarding ash, wheat straw was significantly richer in ash than eucalyptus residues (11.4 wt \% vs. $1.0 \mathrm{wt} \%)$. Similarly, the content of water extractives was much higher in wheat straw than in eucalyptus residues ( $9.4 \mathrm{wt} \%$ vs. $3.3 \mathrm{wt} \%$ ). The observed differences are typical, as wheat straw is a form of herbaceous residue, whereas Eucalyptus globulus is an example of hardwood; the composition of both types of biomasses presented in this work are similar to those described in the literature [34-37]. 
Table 1. Feedstock composition (wheat straw and eucalyptus residues).

\begin{tabular}{lcc}
\hline Components (Dry Weight \%) & Wheat Straw & Eucalyptus Residues \\
\hline Glucan & $35.9 \pm 0.3$ & $44.1 \pm 0.9$ \\
Hemicellulose & 26.7 & 19.6 \\
Xylan & $22.1 \pm 0.6$ & $15.7 \pm 0.2$ \\
Arabinosyl group & $2.0 \pm 0.7$ & $0.5 \pm 0.1$ \\
$\quad$ Acetyl group & $2.6 \pm 0.9$ & $3.4 \pm 0.9$ \\
Lignin & 16.7 & 33.8 \\
$\quad$ Acid-insoluble & $15.5 \pm 0.4$ & $26.4 \pm 0.1$ \\
Acid-soluble & $1.2 \pm 0.1$ & $7.4 \pm 0.1$ \\
Exh & $11.4 \pm 0.1$ & $1.0 \pm 0.1$ \\
$\quad$ Watractiver & $9.4 \pm 1.3$ & $3.3 \pm 0.4$ \\
$\quad$ Ethanol & $1.4 \pm 0.1$ & $1.5 \pm 0.1$ \\
\hline
\end{tabular}

\subsection{Pre-Treatment with Imidazole}

\subsubsection{Wheat Straw}

All performed experiments resulted in two solid fractions composed mainly of polysaccharides (cellulose and hemicellulose). The macromolecular composition of cellulose produced in the pre-treated wheat straw, as well as the percentage of recovered solid fraction, are shown in Figure 2 and Table S1 in the Electronic Supplementary Information.

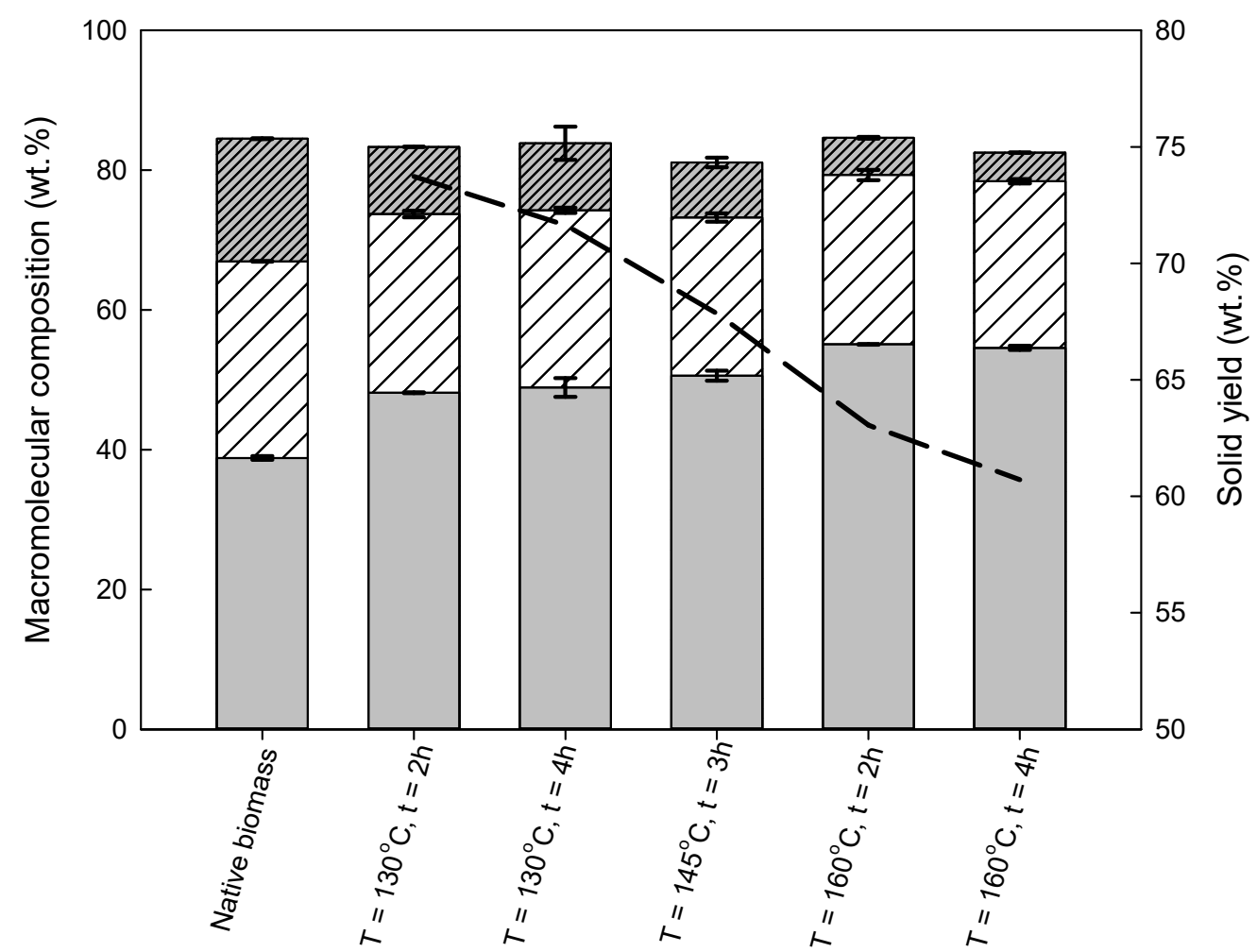

Figure 2. Native wheat straw and solid fraction compositions (wt \%), obtained from pre-treatment with imidazole at varied reaction temperatures and times. The black line represents the recovered solids (wt \%). The cellulose amount, depicted as a grey bar, was measured in terms of glucan content, and hemicellulose, represented as a white bar with a pattern, was measured as the sum of the xylan and arabinosyl group content. Lignin is depicted as a grey bar with a pattern. Ash and other minor components are not shown, for clarity in the figure.

It can be observed that at the mildest temperature studied $\left(130^{\circ} \mathrm{C}\right)$, the highest solid recovery was obtained, with a value of $73.7 \pm 0.6 \mathrm{wt} \%$. An increase in the reaction 
temperature led to a gradual decrease in solids recovery, achieving only $60.7 \pm 0.7 \mathrm{wt} \%$ for the most severe reaction conditions $\left(160^{\circ} \mathrm{C} / 4 \mathrm{~h}\right)$.

The obtained results also demonstrate that temperature is a dominant variable for cellulose recovery. An increase in temperature for the same reaction time, e.g., $2 \mathrm{~h}$, enables enhancing the cellulose content by almost $15 \%$, from $48.2 \pm 0.1 \mathrm{wt} \%$ at $130{ }^{\circ} \mathrm{C}$ to $55.1 \pm 0.1 \mathrm{wt} \%$ at $160{ }^{\circ} \mathrm{C}$. On the other hand, an increase in the reaction time from 2 to $4 \mathrm{~h}$, at the same temperature, showed no influence on the cellulose content in the pre-treated solids.

Regarding the hemicellulose content, an increase in either temperature or reaction time had no influence, changing the hemicellulose content by far less than $15 \%$; e.g., for $130{ }^{\circ} \mathrm{C} / 2 \mathrm{~h}$, it was $25.6 \pm 0.5 \mathrm{wt} \%$, while for $160{ }^{\circ} \mathrm{C} / 2 \mathrm{~h}$, it was $24.2 \pm 0.7 \mathrm{wt} \%$.

The third main fraction of the pre-treated solid is lignin. Similarly, the lignin content was significantly affected by temperature. For example, for $2 \mathrm{~h}$, an increase in the reaction temperature from $130{ }^{\circ} \mathrm{C}$ to $160{ }^{\circ} \mathrm{C}$ resulted in a reduction in lignin content from $9.6 \pm 0.0 \mathrm{wt} \%$ to $5.3 \pm 0.1 \mathrm{wt} \%$. For a double-reaction time and the same range of reaction temperatures, the decrease was even more pronounced; it dropped by almost $60 \%$, i.e., from $9.6 \pm 2.4 \mathrm{wt} \%$ to $4.1 \pm 0.0 \mathrm{wt} \%$.

The alkaline pre-treatment including imidazole disrupts the ester bonds between lignin and hemicellulose, and breaks the hydrogen bonds between lignin, cellulose, and hemicellulose, as demonstrated elsewhere [38]. This makes imidazole a good delignification agent $[26,39]$. The same finding was observed in the present work because the delignification yield, depending on the process conditions, varied from $59.6 \pm 0.5 \mathrm{wt} \%$ to $85.9 \pm 0.3 \mathrm{wt} \%$. At the same time, the cellulose recovery was very high, being $85.4 \pm 3.0 \mathrm{wt} \%$ at $160{ }^{\circ} \mathrm{C} / 4 \mathrm{~h}$, and, at $130{ }^{\circ} \mathrm{C} / 2 \mathrm{~h}$, it was $91.5 \pm 1.8 \mathrm{wt} \%$.

The obtained results are in agreement with the previous work presented in the literature. For example, Morais et al. [15] obtained $62.4 \mathrm{wt} \%$ of cellulose in the solid fraction with a lignin removal of $91.4 \mathrm{wt} \%$, at $170{ }^{\circ} \mathrm{C} / 2 \mathrm{~h}$. This is a significant increase when compared to the results obtained at $110{ }^{\circ} \mathrm{C} / 2 \mathrm{~h}$, i.e., $42.2 \mathrm{wt} \%$ of cellulose content and $54.5 \mathrm{wt} \%$ of lignin removal. Furthermore, they also reported a reduction in solids and hemicellulose recovery with an increase in the reaction temperature. It is worth emphasizing that the temperatures used in the referred work were higher than those reported here. This may explain the differences in the obtained results. Toscan et al. [39] also reported that in the case of elephant grass, the cellulose content increased from $40.3\left(114.4{ }^{\circ} \mathrm{C} / 57 \mathrm{~min}\right)$ to $52.5 \mathrm{wt} \%$ $\left(135.6^{\circ} \mathrm{C} / 308 \mathrm{~min}\right)$, whereas the lignin content dropped from $9.4 \mathrm{wt} \%$ at $125.0^{\circ} \mathrm{C} / 5.0 \mathrm{~min}$ to $4.6 \mathrm{wt} \%$ at $135.6{ }^{\circ} \mathrm{C} / 308 \mathrm{~min}$ (increase in delignification from 50.7 to $81.8 \mathrm{wt} \%$ ). Similarly to this work, they also reported a reduction in the solid recovery yield with an increase in temperature, with an $82.4 \mathrm{wt} \%$ yield for experiments performed at $114.4{ }^{\circ} \mathrm{C} / 57 \mathrm{~min}$, while for $140{ }^{\circ} \mathrm{C} / 182.5 \mathrm{~min}$ the solid recovery yield was only $59.9 \mathrm{wt} \%$ [39].

Comparing the obtained results to those reported in the literature for different biomass pre-treatment technologies, (e.g., organosolv), it can be stated that the imidazole process is very effective for the delignification of biomass. Salapa et al. (2017) analyzed the organosolv pre-treatments of wheat straw [40]. They reported a production of a polysaccharide-rich fraction with $66.6 \mathrm{wt} \%$ of cellulose and $60 \mathrm{wt} \%$ lignin removals for pre-treatment with $50 \%$ $(v / v)$ ethanol at $180{ }^{\circ} \mathrm{C} / 20 \mathrm{~min}$ and $23 \mathrm{mM} \mathrm{H}_{2} \mathrm{SO}_{4}$. However, pre-treatment with $50 \%(v / v)$ acetone at $180{ }^{\circ} \mathrm{C} / 40 \mathrm{~min}$ and $23 \mathrm{mM} \mathrm{H}_{2} \mathrm{SO}_{4}$ allowed to achieve $76.4 \mathrm{wt} \%$ delignification with $67.2 \mathrm{wt} \%$ cellulose. The same authors also studied the biomass processing at $160^{\circ} \mathrm{C}$. At this temperature, the maximum delignification achieved was $65 \mathrm{wt} \%$, with acetone as the solvent, $23 \mathrm{mM} \mathrm{H}_{2} \mathrm{SO}_{4}$ and $40 \mathrm{~min}$ of reaction time. These results are considerably poorer than the delignification achieved in the present work at the same temperature. In addition, Wildschut et al. (2013) studied organosolv pre-treatment of wheat straw [41] and obtained a high-purity polysaccharide fraction with $75 \mathrm{wt} \%$ of cellulose and a delignification of $75 \mathrm{wt} \%$ at $190{ }^{\circ} \mathrm{C} / 1 \mathrm{~h} 60 \%$ aqueous ethanol, with $30 \mathrm{mM} \mathrm{H}_{2} \mathrm{SO}_{4}$. Although these results seem to be better than those reported herein, it is important to emphasize that in both abovementioned works, the temperature used was much higher and additional external 
catalysts were used. Wildschut et al. (2013) studied the influence of temperature on pretreatment without any catalyst and achieved a delignification of only 4.7 and $14.4 \mathrm{wt} \%$ for 160 and $170{ }^{\circ} \mathrm{C}$, respectively [41]. It is also worth mentioning that novel organosolv pre-treatments have been studied at lower temperatures. Park et al. [42] pre-treated corn stover and achieved a $90.3 \mathrm{wt} \%$ delignification with a flow-through process including a $150{ }^{\circ} \mathrm{C} / 60 \mathrm{~min}$ reaction with an aqueous solution of $30 \mathrm{wt} \%$ ethanol and $10 \mathrm{wt} \% \mathrm{H}_{2} \mathrm{O}_{2}$.

It is also important to compare the data obtained in the present work to those reported using ionic liquids (ILs). As a precursor of ILs, imidazole can also be considered a cheaper alternative to ILs in biomass processing [40]. Ren et al. [43] studied the pre-treatment of wheat straw with nine novel renewable cholinium-based ILs and reported a maximum delignification of $68.8 \mathrm{wt} \%$ with cholinium taurate under $\mathrm{N}_{2}$ stirred at $90{ }^{\circ} \mathrm{C} / 6 \mathrm{~h}$, which is a lower temperature than those applied herein. In their study, da Costa Lopes et al. reported a solid fraction with $83.4 \mathrm{wt} \%$ cellulose and only $2.8 \mathrm{wt} \%$ residual lignin, obtained with 1-butyl3-methylimidazolium thiocyanate at $120{ }^{\circ} \mathrm{C}$ for $6 \mathrm{~h}$ with a $5 \mathrm{wt} \%$ biomass/IL ratio [44]. The same authors also studied biomass fractionation with 1-ethyl-3-methylimidazolium acetate, under the abovementioned conditions, and obtained carbohydrate-rich materials and a separated lignin fraction with $87 \mathrm{wt} \%$ purity [45]. Brandt et al. [46] tested a different 1-butyl-3-H-imidazolium hydrogen sulfate ionic liquids and found that this IL was able to remove up to $93 \mathrm{wt} \%$ of the lignin present in the raw material in a process carried out at $120^{\circ} \mathrm{C} / 20 \mathrm{~h}$. Even though ILs allowed achieving similar results at similar temperatures to those used in this work, imidazole has the advantage of being a much cheaper reagent than most of the ILs tested so far.

\subsubsection{Eucalyptus Residues}

To compare the pre-treatment efficiency of both biomasses, the same procedure was applied for the pre-treatment of eucalyptus residues. The macromolecular composition of solid fractions produced during pre-treatment, as well as the percentage of recovered solids from the initial biomass content in the respective fraction, are shown in Figure 3 and Table S2 in the Electronic Supplementary Information. The solids recovery decreased with temperature, from $95.9 \pm 0.1 \mathrm{wt} \%$ at $130{ }^{\circ} \mathrm{C} / 4 \mathrm{~h}$ to $92.0 \pm 0.7 \mathrm{wt} \%$ at $160^{\circ} \mathrm{C} / 4 \mathrm{~h}$; however, the decrease was very low. The eucalyptus residues processing with imidazole under different conditions had almost no effect on the selectivity of this biomass fractionation. The solid fraction composition was almost constant for all the experimental conditions tested. The cellulose content changed from $50.3 \pm 1.2 \mathrm{wt} \%$ to $54.3 \pm 0.2 \mathrm{wt} \%$ for $130{ }^{\circ} \mathrm{C} / 2 \mathrm{~h}$ and $160{ }^{\circ} \mathrm{C} / 4 \mathrm{~h}$, respectively. This means that in pre-treatment of eucalyptus residues with imidazole, cellulose was almost not affected because a quantitatively similar recovery of this macromolecule under all conditions tested was achieved.

When analyzing the lignin recovery, it can be stated that the pre-treatment of eucalyptus residues with imidazole has little, if any, apparent effect in experimental conditions on the lignin content. For all tested conditions, the lignin content varied from $17.1 \pm 0.9$ to $15.9 \pm 0.4 \mathrm{wt} \%$. Consequently, almost no change in the delignification yield was observed. In the range of studied conditions, the removal of lignin was between $52.6 \mathrm{wt} \%$ and $56.6 \mathrm{wt} \%$ for the least and the most severe reaction conditions, respectively.

Other studies of the pre-treatment of eucalyptus residues with acidic ionic liquids also demonstrated that delignification is very limited, and that cellulose can be recovered in quantitative amounts. Only in the switch to a hydrogen-bond alkaline ionic liquid, namely, 1-ethyl-3-methylimidazolium acetate, were the eucalyptus residues pre-treated more efficiently; as little as 0.7 or $1.0 \mathrm{wt} \%$ of lignin was found in the solid fractions produced at $120^{\circ} \mathrm{C} / 2 \mathrm{~h}$ and $140{ }^{\circ} \mathrm{C} / 2 \mathrm{~h} \mathrm{[34]}$. 


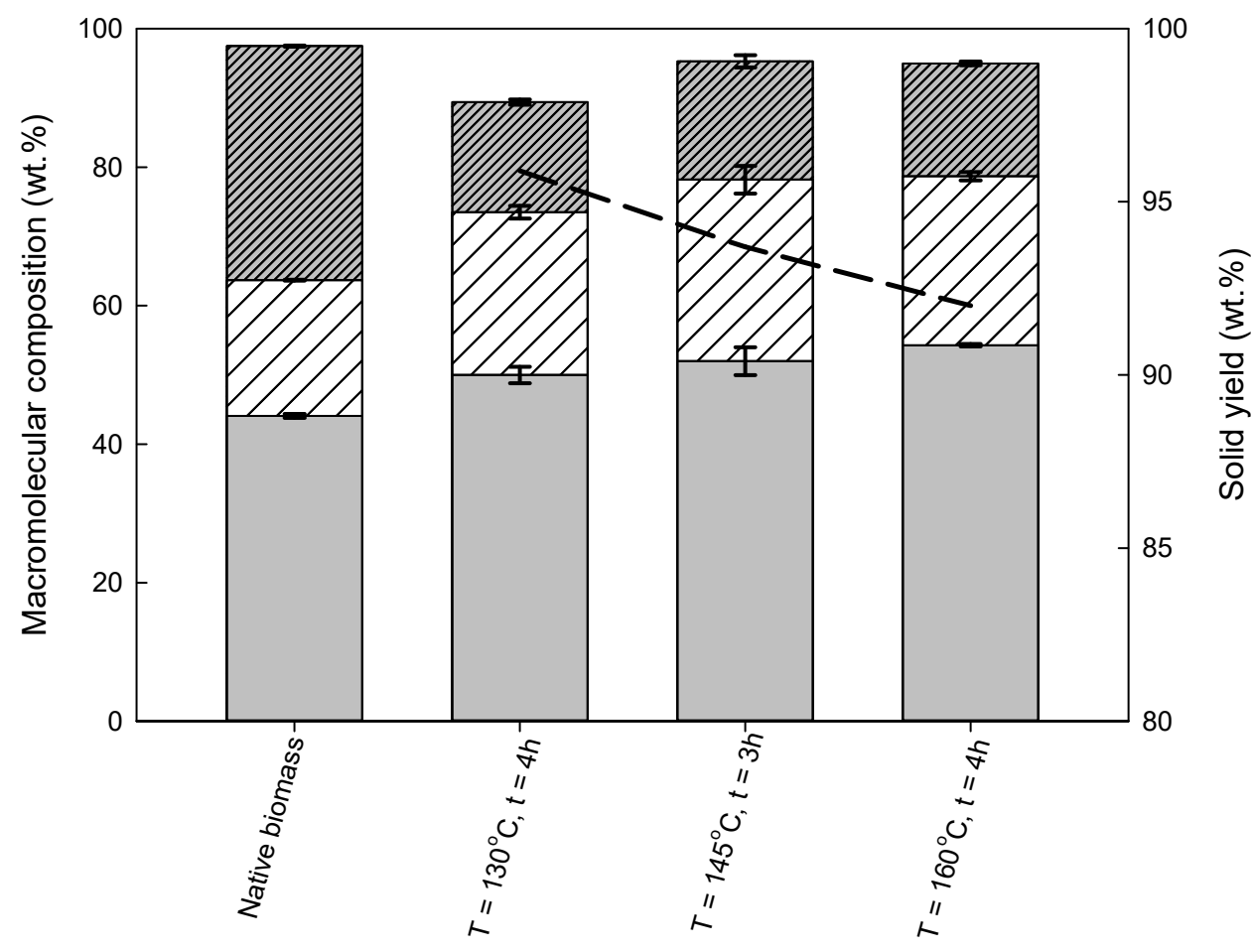

Figure 3. Native eucalyptus residues and solid fraction compositions (wt \%), obtained from pretreatment with imidazole at varied reaction temperatures and times. The black line represents the recovered solids (wt \%). The cellulose amount depicted as the grey bar was measured as the glucan content. The hemicellulose amount represented as the white bar with a pattern was measured as the sum of xylan and arabinosyl group contents. Lignin content is depicted as the grey bar with a pattern. The contents of ash and other minor components are not shown for the clarity of the figure.

\subsubsection{Comparison between Wheat Straw and Eucalyptus Residues Pre-Treatments}

Both biomasses were subjected to the same pre-treatment procedure, where two variables (temperature and time) were studied. This protocol enables the comparison of the pre-treatment efficiency in two different feedstock origins: agriculture and forest. The efficiency was evaluated in terms of purity of the solid fraction and hemicellulose and lignin removal.

In general, the temperature had a similar effect on the solid yields, as with an increase in temperature, the solids recovery decreased for both biomasses. Regarding the solid fraction, the lowest cellulose content was achieved under the mildest conditions $\left(48.2 \pm 0.1 \mathrm{wt} \%\right.$ at $\left.130{ }^{\circ} \mathrm{C}\right)$, for wheat straw. By contrast, in terms of eucalyptus residues, the lowest cellulose content was achieved for pre-treatment with imidazole after $3 \mathrm{~h}$ at $145^{\circ} \mathrm{C}(52.7 \pm 0.4 \mathrm{wt} \%)$. The highest cellulose content was achieved for the most severe conditions used in this study, i.e., at $160{ }^{\circ} \mathrm{C} / 4 \mathrm{~h}$, and was similar for both biomasses $-55.1 \pm 0.1 \mathrm{wt} \%$ and $54.3 \pm 0.2 \mathrm{wt} \%$, for wheat straw and eucalyptus residues, respectively.

Analyzing the data presented above, it can also be concluded that for wheat straw, lignin and hemicellulose recoveries decrease with temperature, while the cellulose recovery showed negligible changes. Therefore, this difference indicates that the purity of cellulose in the solid fraction increases with temperature, and this conclusion is valid for both biomasses studied.

A significant difference between both biomasses was observed in terms of lignin removal. The lignin content in the solid fraction of wheat straw decreased considerably with temperature, while in the processed eucalyptus residues, the lignin content showed negligible changes under pre-treatment conditions. In addition, wheat straw pre-treatment reached delignification yields as high as $85.9 \pm 0.3 \mathrm{wt} \%$ at $160{ }^{\circ} \mathrm{C} / 4 \mathrm{~h}$, indicating that 
imidazole is more efficient in the delignification of wheat straw than of eucalyptus residues, for which the delignification yield was only $56.6 \pm 0.3 \mathrm{wt} \%$ under the same conditions. One of the reasons for this might be that hardwoods are more recalcitrant than herbaceous and agricultural residues, making their pre-treatment more challenging. This is probably attributed to their more rigid structure and higher lignin content, compared to the two others [47]. Most of the lignin in wood is bonded to hemicellulose components like a cementing agent, resulting in a complex and inaccessible structure. The differences observed in this work could also be due to variations in the lignin-carbohydrate association, the lignin distribution, or the lignin structure itself in agricultural residues and softwoods, which is mostly composed of guaiacyl units, while agricultural wastes contain not only guaiacyl but also syringyl and p-hydroxyphenyl units [48]. Thus, it can be concluded that although biomass fractionation with imidazole is possible, the process is less efficient with wood than with herbaceous biomass and others, as is also described in the literature $[45,48,49]$.

Comparing the results of both biomasses pre-treated with imidazole to those presented in the literature for ionic liquid pre-treatment [34], some similarities can be noted. For example, the pre-treatment of both biomasses with 1-ethyl-3-methylimidazolium acetate at $120{ }^{\circ} \mathrm{C} / 2 \mathrm{~h}$ produced solids with a very similar cellulose content, i.e., $65.8 \mathrm{wt} \%$ and $66.7 \mathrm{wt} \%$ for wheat straw and eucalyptus residues, respectively. Furthermore, the observed higher lignin content in processed eucalyptus residues was also found for the same ionic liquid. The lignin content in pre-treated eucalyptus residues was as high as $23.1 \mathrm{wt} \%$, while for the pre-treated wheat straw, it was $17.2 \mathrm{wt} \%$ [34].

\subsection{Enzymatic Hydrolysis}

To evaluate the influence of a pre-treatment method on reducing sugars production, the native biomasses and recovered solids were subjected to enzymatic hydrolysis. The results are depicted in Figures 4 and 5 and Tables S3 and S4 in the Electronic Supplementary Information for wheat straw and Figures 6 and 7 Tables S5 and S6 in the Electronic Supplementary Information for eucalyptus residues.

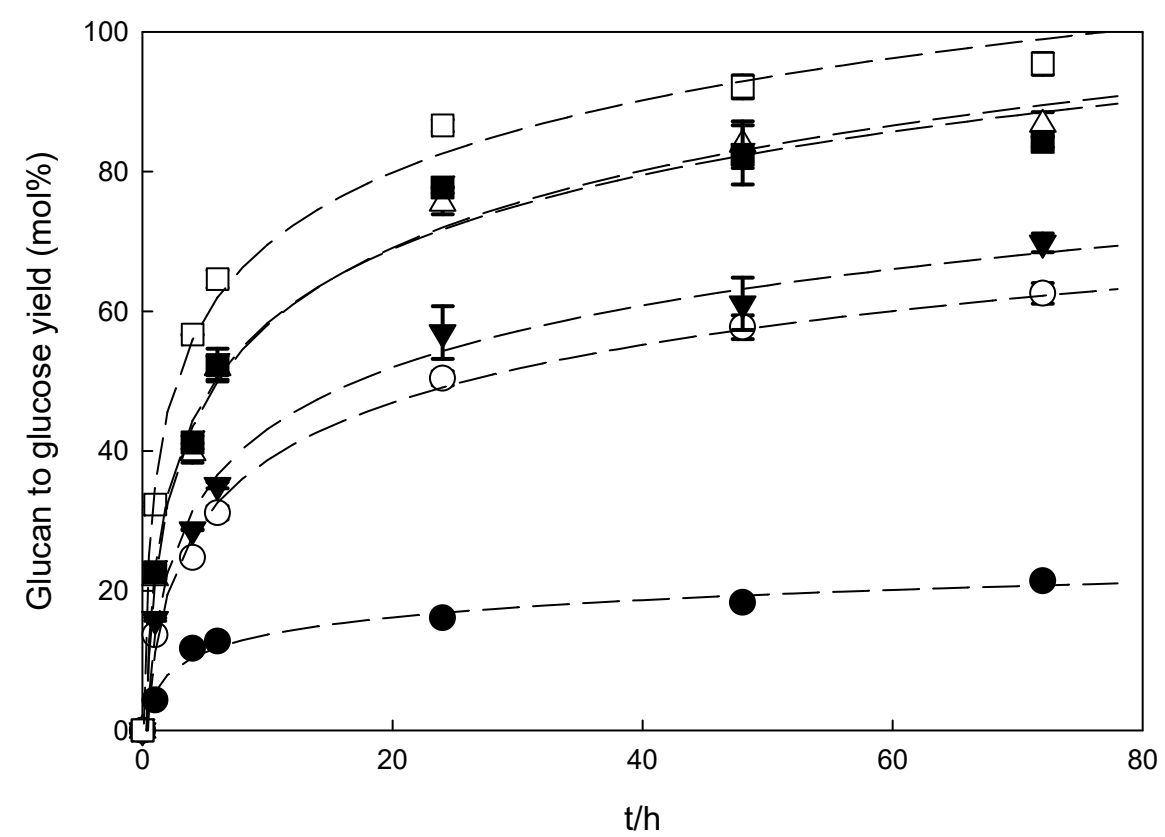

Figure 4. Glucan to glucose yields of wheat straw pre-treated solids that were produced by imidazole pre-treatment. The enzymatic hydrolyses were performed at $2 \%(w / v)$ total solids with $60 \mathrm{FPU} / \mathrm{g}$ glucan of Cellic CTec2. The dashed lines are only used as a guide for the eye and have no physical meaning. 


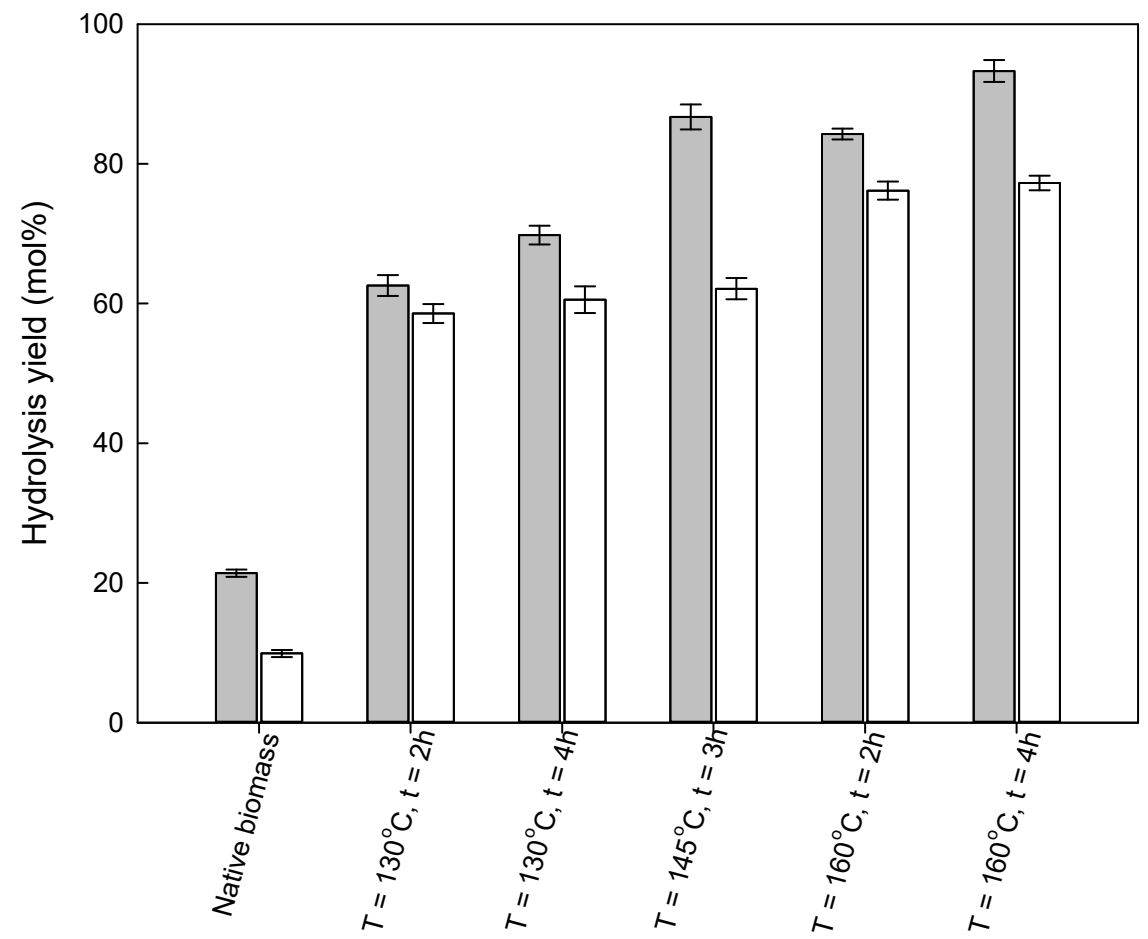

Figure 5. Glucan to glucose (grey bar) and xylan to xylose saccharification (white bar) yields, over $72 \mathrm{~h}$ of enzymatic hydrolysis time of wheat straw pre-treated solids, as a function of the pre-treatment conditions. The enzymatic hydrolysis yields for native wheat straw are presented for comparison.

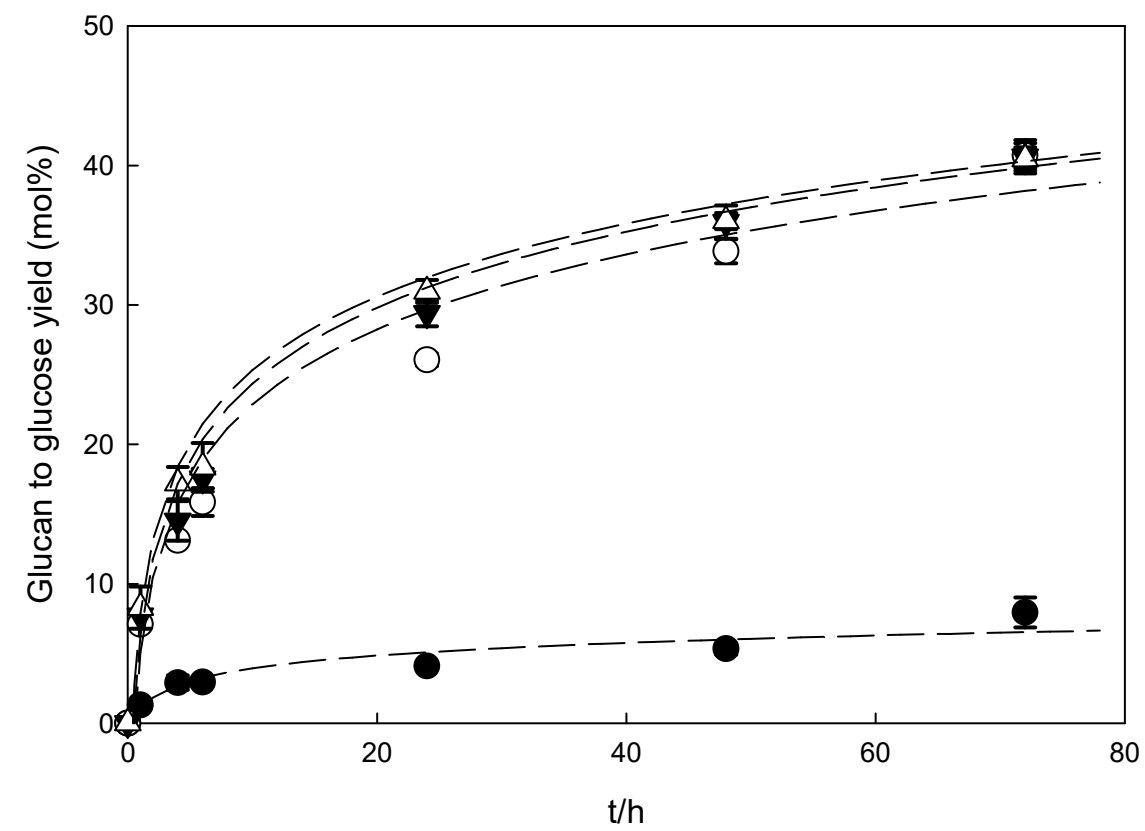

Figure 6. Glucan to glucose yields that were produced by an imidazole pre-treatment of eucalyptus residues. The enzymatic hydrolyses were performed at $2 \%(w / v)$ total solids with $60 \mathrm{FPU} / \mathrm{g}$ glucan of Cellic CTec2. The dashed lines are only used as a guide for the eye and have no physical meaning. 


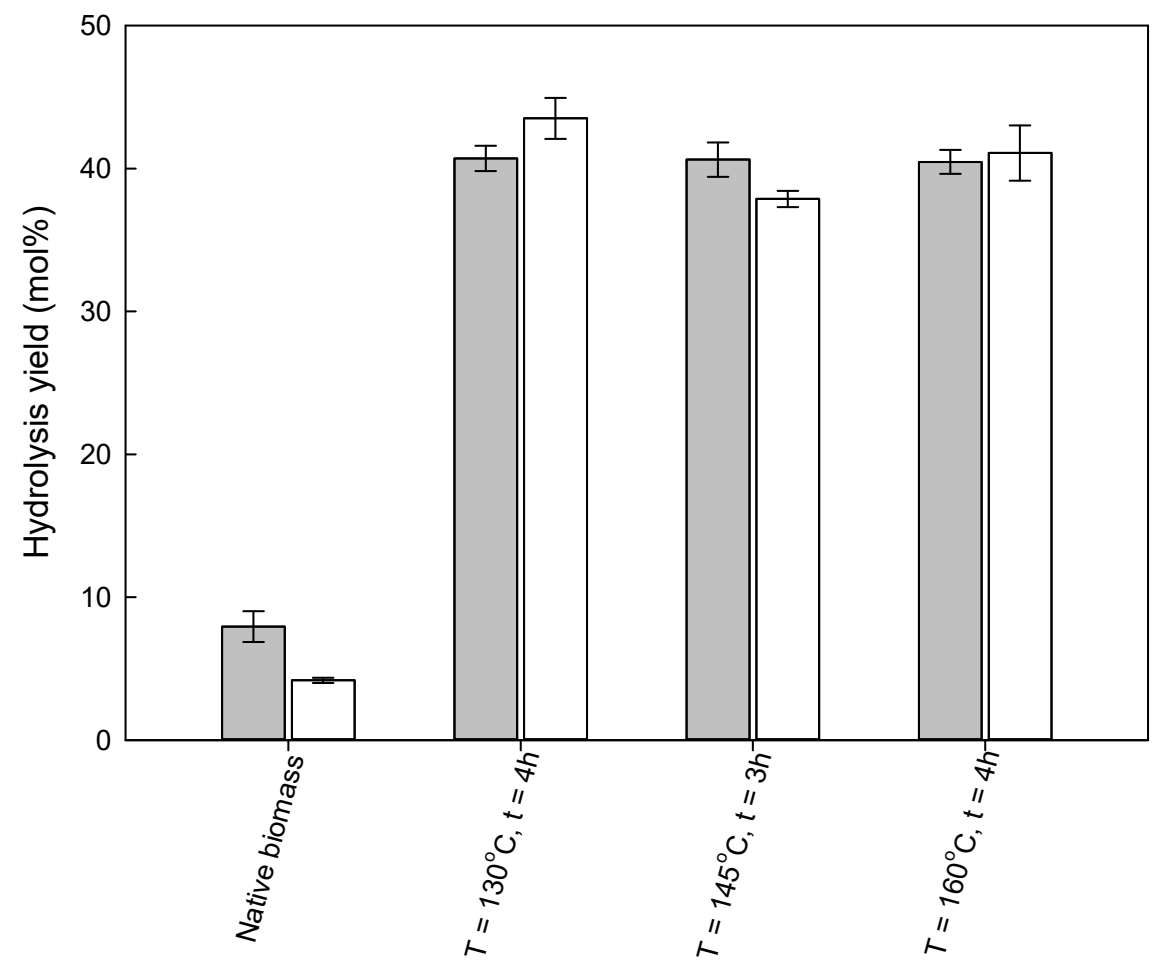

Figure 7. Glucan to glucose (grey bar) and xylan to xylose saccharification (white bar) yields for $72 \mathrm{~h}$ of enzymatic hydrolysis of eucalyptus residues as a function of the pre-treatment conditions. The enzymatic hydrolysis yields for native wheat straw are presented for comparison.

In general, the glucan to glucose yield increased for all the samples obtained after pre-treatment with imidazole; however, the enzymatic digestibility of the polysaccharide was strongly dependent on the pre-treatment conditions and the biomass used. For both biomasses, an increase in the hydrolysis time resulted in an increase in either glucose or xylose released for all samples tested.

Figures 4 and 5 demonstrate that with an increase in the severity of pre-treatment conditions (temperature and time of reaction), an increase in the enzymatic digestibility of pre-treated wheat straw was observed. These results were expected since either temperature or time affect the composition of the recovered solids, as discussed above. A maximum glucan to glucose yield was achieved after $72 \mathrm{~h}$ of enzymatic hydrolysis for the solids subjected to the most severe pre-treatment conditions $\left(160^{\circ} \mathrm{C} / 4 \mathrm{~h}\right)$, obtaining $93.3 \pm 1.6 \mathrm{~mol} \%$ and $77.3 \pm 1.0 \mathrm{~mol} \%$ for glucan to glucose and xylan to xylose yields, respectively. In a previous report [15], it was demonstrated that temperature played an important role in improving the enzymatic hydrolysis of solids obtained in the pre-treatment of wheat straw with imidazole. An increase in process temperature from 130 to $160{ }^{\circ} \mathrm{C}$ for $2 \mathrm{~h}$ pre-treatment time resulted in an increase in the glucose yield from $62.6 \pm 1.5$ to $84.3 \pm 0.8 \mathrm{~mol} \%$, an increase by $193 \%$ and $294 \%$, respectively, in comparison to native biomass.

Pre-treatment time also affects enzymatic hydrolysis and an increase in the reaction time leads to an increase in the glucan to glucose yield. However, in this case, the difference is less pronounced. For both temperatures, $130^{\circ} \mathrm{C}$ and $160^{\circ} \mathrm{C}$, an increase in pre-treatment time from 2 to $4 \mathrm{~h}$ enabled an increase in the glucan to glucose yield by $11.6 \%$ and $10.8 \%$, respectively. Hence, in the case of wheat straw, the main factor influencing the enzymatic hydrolysis is the pre-treatment temperature.

The enzymatic digestibility of polysaccharide fractions is strongly dependent on several factors and one of the main factors influencing the enzymatic hydrolysis is the lignin content. The obtained results demonstrated that a linear relation exists (Glucan to glucose yield $(\mathrm{mol} \%)=122.97 *$ delignification $(\%(\mathrm{w} / \mathrm{w})-9.465, \mathrm{R} 2=0.94)$ between the biomass delignification and the efficiency of enzymatic digestibility. The extensive re- 
moval of lignin favors enzymatic hydrolysis, confirming that lignin is one of the most important inhibitors of efficient enzymatic hydrolysis.

Analogous to wheat straw, the pre-treatment of eucalyptus residues with imidazole improved the enzymatic hydrolysis, especially when compared to the native biomass, as demonstrated in Figures 6 and 7. However, in this case, the yield of enzymatic hydrolysis was almost independent of pre-treatment conditions, obtaining $40 \mathrm{~mol} \%$ for the glucan to glucose yield after $72 \mathrm{~h}$ of enzymatic hydrolysis for all conditions tested. Even an increase in hydrolysis time to $144 \mathrm{~h}$ allowed only a small increase in the glucan to glucose yield, to merely $47.6 \pm 0.9 \%$.

Although imidazole pre-treatment resulted in a four-fold increase in glucose yields in comparison to native biomass, the hydrolysis yields detected were lower than those observed for wheat straw (2.3-fold lower). This difference again confirms that the biomass type is crucial in efficient biomass processing for obtaining a high enzymatic hydrolysis yield. Similar conclusions were drawn in the case of ionic liquid pre-treatment with the same biomasses [34], where it was demonstrated that, besides the lignin removal, a change in cellulose crystallinity is fundamental to achieve the efficient release of reducing sugar.

\section{Conclusions}

The performed studies demonstrated that imidazole can be considered a potential solvent for biomass pre-treatment. Imidazole allowed us to separate the main fractions of wheat straw and to produce pre-treated solids. Such solids were shown to be suitable feedstock for reducing sugar production. On the other hand, eucalyptus residues were demonstrated to be much more resistant to imidazole processing; very limited delignification of this residue was achieved in the range of studied conditions. This, in turn, resulted in a very low enzymatic hydrolysis yield.

Therefore, imidazole was shown to be efficient for the treatment of herbaceous residues, whereas for hardwood, within the range of studied conditions, imidazole was not the best choice. These results confirm that the efficiency of pre-treatment, as well as subsequent enzymatic hydrolysis yield, are dictated by the reaction solvent and the properties of the processed biomass.

Supplementary Materials: The following are available online, Table S1: Composition of solid fractions obtained from wheat straw pre-treated with imidazole, Table S2: Composition of solid fractions obtained from eucalyptus residues pre-treated with imidazole, Table S3: Glucan-to-glucose yield $(\mathrm{mol} \%)$ of wheat straw pre-treated solids that were produced by imidazole pre-treatment, Table S4: Glucan to glucose and xylan to xylose saccharification yield (mol\%) for $72 \mathrm{~h}$ of enzymatic hydrolysis time of wheat straw pre-treated solids as a function of the pre-treatment conditions, Table S5: Glucan-to-glucose yield ( $\mathrm{mol} \%$ ) of eucalyptus residues pre-treated solids that were produced by imidazole pre-treatment, Table S6: Glucan to glucose and xylan to xylose saccharification yield $(\mathrm{mol} \%)$ for $72 \mathrm{~h}$ of enzymatic hydrolysis time of wheat straw pre-treated solids as a function of the pre-treatment conditions.

Author Contributions: Conceptualization, R.M.Ł. and L.B.R.; methodology, R.M.Ł.; validation, R.M.Ł., L.B.R. and F.G.; formal analysis, J.R.B. and R.M.Ł.; investigation, P.M.A.P. and J.R.B.; resources, F.G. and R.M.Ł.; data curation, J.R.B. and L.B.R.; writing-original draft preparation, J.R.B. and P.M.A.P.; writing-review and editing, R.M.Ł., L.B.R. and F.G.; visualization, R.M.Ł.; supervision, R.M.Ł. and L.B.R.; project administration, F.G. and R.M.Ł.; funding acquisition, F.G. and R.M.Ł. All authors have read and agreed to the published version of the manuscript.

Funding: This research was funded under the AMBITION (Advanced biofuel production with energy system integration work) project funded by the European H2020-programme under the LCE-33 2016 European Common Research and Innovation Agendas (ECRIAs), in support of the implementation of the SET Action Plan, Grant Agreement 731263. This work was also supported by the Fundação para a Ciência e a Tecnologia (FCT, Portugal) through BBRI-Biomass and Bioenergy Research Infrastructure (ROTEIRO/0189/2013) and grant IF/00471/2015 (RML).

Institutional Review Board Statement: Not applicable. 
Informed Consent Statement: Not applicable.

Data Availability Statement: The data presented in this study are available in supplementary material.

Acknowledgments: The authors wish to thank Susana Marques (UB, LNEG) for the conceptualization of the enzymatic hydrolysis assays, as well as Maria do Céu Penedo (UB, LNEG) for her assistance with the HPLC analyses.

Conflicts of Interest: The authors declare no conflict of interest. The funders had no role in the design of the study; in the collection, analyses, or interpretation of data; in the writing of the manuscript, or in the decision to publish the results.

Sample Availability: Not applicable.

\section{References}

1. Nurek, T.; Gendek, A.; Roman, K. Forest residues as a renewable source of energy: Elemental composition and physical properties. BioResources 2019, 14, 6-20. [CrossRef]

2. Hrbek, J. Past, present and future of thermal gasification of biomass and waste. Acta Innov. 2020, 35, 5-20. [CrossRef]

3. Roman, K.; Barwicki, J.; Rzodkiewicz, W.; Dawidowski, M. Evaluation of mechanical and energetic properties of the forest residues shredded chips during briquetting process. Energies 2021, 14, 3270. [CrossRef]

4. Manzanares, P. The role of biorefinering research in the development of a modern bioeconomy. Acta Innov. 2020, 37, 47-56. [CrossRef]

5. Harmsen, P.; Huijgen, W.; Bermudez, L.; Bakker, R. Literature Review of Physical and Chemical Pretreatment Processes for Lignocellulosic Biomass; Wageningen UR-Food \& Biobased Research: Wageningen, The Netherlands, 2010.

6. Peleteiro, S.; Rivas, S.; Alonso, J.L.; Santos, V.; Parajó, J.C. Furfural production using ionic liquids: A review. Bioresour. Technol. 2016, 202, 181-191. [CrossRef] [PubMed]

7. Kumar, S.; Ahluwalia, V.; Kundu, P.; Sangwan, R.S.; Kansal, S.K.; Runge, T.M.; Elumalai, S. Improved levulinic acid production from agri-residue biomass in biphasic solvent system through synergistic catalytic effect of acid and products. Bioresour. Technol. 2018, 251, 143-150. [CrossRef] [PubMed]

8. Kochepka, D.M.; Dill, L.P.; Fockink, D.H.; Łukasik, R.M. Contribution to the production and use of biomass-derived solvents-A review. Acta Innov. 2020, 35, 29-56. [CrossRef]

9. Silveira, M.H.L.; Morais, A.R.C.; Da Costa Lopes, A.M.; Olekszyszen, D.N.; Bogel-Łukasik, R.; Andreaus, J.; Pereira Ramos, L. Current pretreatment technologies for the development of cellulosic ethanol and biorefineries. ChemSusChem 2015, 8, 3366-3390. [CrossRef] [PubMed]

10. Gírio, F.M.; Fonseca, C.; Carvalheiro, F.; Duarte, L.C.; Marques, S.; Bogel-Łukasik, R. Hemicelluloses for fuel ethanol: A review. Bioresour. Technol. 2010, 101, 4775-4800. [CrossRef]

11. Gillet, S.; Aguedo, M.; Petitjean, L.; Morais, A.R.C.; Da Costa Lopes, A.M.; Łukasik, R.M.; Anastas, P.T. Lignin transformations for high value applications: Towards targeted modifications using green chemistry. Green Chem. 2017, 19, 4200-4233. [CrossRef]

12. Brandt-Talbot, A.; Gschwend, F.J.V.; Fennell, P.S.; Lammens, T.M.; Tan, B.; Weale, J.; Hallett, J.P. An economically viable ionic liquid for the fractionation of lignocellulosic biomass. Green Chem. 2017, 19, 3078-3102. [CrossRef]

13. Zhang, L.X.; Yu, H.B. Conversion of xylan and xylose into furfural in biorenewable deep eutectic solvent with trivalent metal chloride added. Bioresources 2013, 8, 6014-6025. [CrossRef]

14. Jordan, T.; Schmidt, S.; Liebert, T.; Heinze, T. Molten imidazole-A starch solvent. Green Chem. 2014, 16, 1967-1973. [CrossRef]

15. Morais, A.R.C.; Pinto, J.V.; Nunes, D.; Roseiro, L.B.; Oliveira, M.C.; Fortunato, E.; Bogel-Łukasik, R. Imidazole: Prospect solvent for lignocellulosic biomass fractionation and delignification. ACS Sustain. Chem. Eng. 2016, 4, 1643-1652. [CrossRef]

16. Chen, L.; Sharifzadeh, M.; Mac Dowell, N.; Welton, T.; Shah, N.; Hallett, J.P. Inexpensive ionic liquids: [HSO4]--based solvent production at bulk scale. Green Chem. 2014, 16, 3098-3106. [CrossRef]

17. Da Costa Lopes, A.M.; Lins, R.M.G.G.; Rebelo, R.A.; Lukasik, R.M.; Łukasik, R.M. Biorefinery approach for lignocellulosic biomass valorisation with an acidic ionic liquid. Green Chem. 2018, 20, 4043-4057. [CrossRef]

18. Hyvarinen, S.; Mikkola, J.P.; Murzin, D.Y.; Vaher, M.; Kaljurand, M.; Koel, M. Sugars and sugar derivatives in ionic liquid media obtained from lignocellulosic biomass: Comparison of capillary electrophoresis and chromatographic analysis. Catal. Today 2014, 223, 18-24. [CrossRef]

19. Rodríguez, H. Ionic liquids in the pretreatment of lignocellulosic biomass. Acta Innov. 2021, 38, 23-36. [CrossRef]

20. Fockink, D.H.; Morais, A.R.C.; Ramos, L.P.; Łukasik, R.M. Insight into the high-pressure CO2 pre-treatment of sugarcane bagasse for a delivery of upgradable sugars. Energy 2018, 151, 536-544. [CrossRef]

21. Özbek, H.N.; Fockink, D.H.; Yanık, D.K.; Göğüş, F.; Lukasik, R. The green biorefinery concept for the valorisation of pistachio shell by high-pressure CO2/H2O system. J. Clean. Prod. 2018, 196, 842-851. [CrossRef]

22. Morais, A.R.C.; Matuchaki, M.D.D.J.; Andreaus, J.; Bogel-Lukasik, R. A green and efficient approach to selective conversion of xylose and biomass hemicellulose into furfural in aqueous media using high-pressure CO2 as a sustainable catalyst. Green Chem. 2016, 18, 2985-2994. [CrossRef] 
23. Zhang, C.W.; Xia, S.Q.; Ma, P.S. Facile pretreatment of lignocellulosic biomass using deep eutectic solvents. Bioresour. Technol. 2016, 219, 1-5. [CrossRef]

24. Paiva, A.; Craveiro, R.; Aroso, I.; Martins, M.; Reis, R.L.; Duarte, A.R.C. Natural deep eutectic solvents-Solvents for the 21st Century. ACS Sustain. Chem. Eng. 2014, 2, 1063-1071. [CrossRef]

25. Pereira, P.M.A.; Bernardo, J.R.; Oliveira, M.C.; Roseiro, L.B.; Łukasik, R.M. Depolymerization of lignin from extracted solid waste of cupressus lusitanica Mill. Biomass using imidazole. Waste Biomass Valorization 2021, 12, 1341-1355. [CrossRef]

26. Toscan, A.; Fontana, R.C.; Andreaus, J.; Camassola, M.; Lukasik, R.M.; Dillon, A.J.P. New two-stage pretreatment for the fractionation of lignocellulosic components using hydrothermal pretreatment followed by imidazole delignification: Focus on the polysaccharide valorization. Bioresour. Technol. 2019, 285, 121346. [CrossRef] [PubMed]

27. Xu, C.P.; Arancon, R.A.D.; Labidi, J.; Luque, R. Lignin depolymerisation strategies: Towards valuable chemicals and fuels. Chem. Soc. Rev. 2014, 43, 7485-7500. [CrossRef] [PubMed]

28. Zhang, Z.; Harrison, M.D.; Rackemann, D.W.; Doherty, W.O.S.; O'Hara, I.M. Organosolv pretreatment of plant biomass for enhanced enzymatic saccharification. Green Chem. 2016, 18, 360-381. [CrossRef]

29. Sluiter, A.; Hames, B.; Ruiz, R.; Scarlata, C.; Sluiter, J.; Templeton, D.; Crocker, D. Determination of Structural Carbohydrates and Lignin in Biomass - Laboratory Analytical Procedure (LAP); National Renewable Energy Laboratory: Golden, CO, USA, 2011.

30. Sluiter, A.; Ruiz, R.; Scarlata, C.; Sluiter, J.; Templeton, D. Determination of Extractives in Biomass; National Renewable Energy Laboratory: Golden, CO, USA, 2008.

31. Sluiter, A.; Hames, B.; Ruiz, R.; Scarlata, C.; Sluiter, J.; Templeton, D. Determination of Ash in Biomass. NREL Laboratory Analytical Procedure (LAP); National Renewable Energy Laboratory: Golden, CO, USA, 2008.

32. International Organization for Standarization. Milk and Milk Products_Determination of Nitrogen Content-Part 1: Kjeldahl Principle and Crude Protein Calculation; International Organization for Standarization: London, UK, 2014.

33. Selig, M.; Weiss, N.; Ji, Y. Enzymatic Saccharification of Lignocellulosic Biomass: Laboratory Analytical Procedure (LAP): Issue Date, 3/21/2008; National Renewable Energy Laboratory-NREL: Golden, CO, USA, 2008.

34. Bernardo, J.R.; Gírio, F.M.; Łukasik, R.M. The effect of the chemical character of ionic liquids on biomass pre-treatment and posterior enzymatic hydrolysis. Molecules 2019, 24, 808. [CrossRef]

35. Aguayo, M.G.; Mendonça, R.T.; Martínez, P.; Rodríguez, J.; Pereira, M. Chemical characteristics and kraft pulping of tension wood from Eucalyptus globulus Labill. Rev. Arvore 2012, 36, 1163-1172. [CrossRef]

36. Garrote, G.; Parajo, J.C. Non-isothermal autohydrolysis of Eucalyptus wood. Wood Sci. Technol. 2002, 36, 111-123. [CrossRef]

37. Magalhães da Silva, S.P.; Morais, A.R.C.; Bogel-Łukasik, R. The CO2-assisted autohydrolysis of wheat straw. Green Chem. 2014, 16, 238-246. [CrossRef]

38. Chaudhary, G.; Singh, L.K.; Ghosh, S. Alkaline pretreatment methods followed by acid hydrolysis of Saccharum spontaneum for bioethanol production. Bioresour. Technol. 2012, 124, 111-118. [CrossRef]

39. Toscan, A.; Morais, A.R.C.; Paixão, S.M.; Alves, L.; Andreaus, J.; Camassola, M.; Dillon, A.J.P.; Lukasik, R.M. Effective extraction of lignin from elephant grass using imidazole and its effect on enzymatic saccharification to produce fermentable sugars. Ind. Eng. Chem. Res. 2017, 56, 5138-5145. [CrossRef]

40. Salapa, I.; Katsimpouras, C.; Topakas, E.; Sidiras, D. Organosolv pretreatment of wheat straw for efficient ethanol production using various solvents. Biomass Bioenergy 2017, 100, 10-16. [CrossRef]

41. Wildschut, J.; Smit, A.T.; Reith, J.H.; Huijgen, W.J.J. Ethanol-based organosolv fractionation of wheat straw for the production of lignin and enzymatically digestible cellulose. Bioresour. Technol. 2013, 135, 58-66. [CrossRef]

42. Park, Y.C.; Kim, J.S.; Kim, T.H. Pretreatment of corn stover using organosolv with hydrogen peroxide for effective enzymatic saccharification. Energies 2018, 11, 1301. [CrossRef]

43. Ren, H.; Zong, M.H.; Wu, H.; Li, N. Efficient pretreatment of wheat straw using novel renewable cholinium ionic liquids to improve enzymatic saccharification. Ind. Eng. Chem. Res. 2016, 55, 1788-1795. [CrossRef]

44. da Costa Lopes, A.M.; João, K.G.; Bogel-Łukasik, E.; Roseiro, L.B.; Bogel-Łukasik, R. Pretreatment and fractionation of wheat straw using various ionic liquids. J. Agric. Food Chem. 2013, 61, 7874-7882. [CrossRef] [PubMed]

45. da Costa Lopes, A.M.; João, K.G.; Rubik, D.F.; Bogel-Łukasik, E.; Duarte, L.C.; Andreaus, J.; Bogel-Łukasik, R. Pre-treatment of lignocellulosic biomass using ionic liquids: Wheat straw fractionation. Bioresour. Technol. 2013, 142, 198-208. [CrossRef]

46. Brandt, A.; Ray, M.J.; To, T.Q.; Leak, D.J.; Murphy, R.J.; Welton, T. Ionic liquid pretreatment of lignocellulosic biomass with ionic liquid-water mixtures. Green Chem. 2011, 13, 2489-2499. [CrossRef]

47. Elmac1, S.B.; Ozcelik, F. Ionic liquid pretreatment of yellow pine followed by enzymatic hydrolysis and fermentation. Biotechnol. Prog. 2018, 34, 1242-1250. [CrossRef] [PubMed]

48. Sun, N.; Rahman, M.; Qin, Y.; Maxim, M.L.; Rodriguez, H.; Rogers, R.D. Complete dissolution and partial delignification of wood in the ionic liquid 1-ethyl-3-methylimidazolium acetate. Green Chem. 2009, 11, 646-655. [CrossRef]

49. Magalhães da Silva, S.P.; da Costa Lopes, A.M.; Roseiro, L.B.; Bogel-Łukasik, R. Novel pre-treatment and fractionation method for lignocellulosic biomass using ionic liquids. RSC Adv. 2013, 3, 16040. [CrossRef] 